Marquette University Law School

Marquette Law Scholarly Commons

Faculty Publications

Faculty Scholarship

$1-1-2012$

\title{
Muted Message: Capital Punishment in the Hollywood Cinema
}

David Ray Papke

Marquette University Law School, david.papke@marquette.edu

Follow this and additional works at: http://scholarship.law.marquette.edu/facpub

Part of the Law Commons

Publication Information

David Ray Papke, Muted Message: Capital Punishment in the Hollywood Cinema, 2 Journalism \& Mass Comm. 1019 (2012)

\section{Repository Citation}

Papke, David Ray, "Muted Message: Capital Punishment in the Hollywood Cinema" (2012). Faculty Publications. Paper 634.

http://scholarship.law.marquette.edu/facpub/634

This Article is brought to you for free and open access by the Faculty Scholarship at Marquette Law Scholarly Commons. It has been accepted for inclusion in Faculty Publications by an authorized administrator of Marquette Law Scholarly Commons. For more information, please contact 


\title{
Muted Message: Capital Punishment in the Hollywood Cinema
}

\author{
David Ray Papke \\ Marquette University, Milwaukee, USA
}

\begin{abstract}
Contemporary Hollywood films seem at first glance to be opposed to capital punishment. However, this article's consideration of five surprisingly similar films (Dead Man Walking, The Chamber, Last Dance, True Crime, and The Life of David Gale) finds that they do not truly and consistently condemn capital punishment. Instead of suggesting that the practice of capital punishment is fundamentally immoral and should in general be ended, the films champion only worthy individuals on death row and delight primarily in the personal growth of other characters who attempt to aid the condemned. In the end, Hollywood offers only a muted message regarding the on-going use of capital punishment.
\end{abstract}

Keywords: capital punishment, death penalty, death row, film, Hollywood cinema

\section{Introduction}

The use of capital punishment in the United States over the last 40 years has fluctuated, largely due to United States Supreme Court rulings and changes in legal procedures made in response to those rulings. In 1972, the United States Supreme Court ruled in Furman v. Georgia that the proceedings in a group of capital punishment cases were unconstitutional, and as a result of the decision, the use of capital punishment ground virtually to a stop (Banner, 2002). However, since the five-Justice majority in Furman v. Georgia did not provide a unified reason for their decision, the general question of capital punishment's constitutionality was left open. Then, in 1976, the Supreme Court ruled in Gregg v. Georgia that a capital crimes proceeding which was separated into guilt-innocence and sentencing phases could be constitutional. In the opinion of one disappointed commentator, "The ultimate question of the death penalty's constitutionality had been laid to rest" (Banner, 2002, p. 275).

The use of capital punishment did not immediately surge after the Gregg decision, but it did pick up in the mid-1980s and reached new highs in the mid-1900s as states began to employ new, constitutionally acceptable procedures. Over 1,300 people have now been executed since the Gregg decision, with Texas accounting for over a third and Virginia, Oklahoma, and Florida being, in order, the next most frequent users of state-authorized execution. Almost $99 \%$ of those executed have been men, and while in earlier eras the methods of capital punishment included such things as firing squads, hanging, electrocution, and the infamous "gas chamber", in the present lethal injection accounts for almost all executions. Short of execution, thousands of prisoners live for years and years in horrendous "death rows", with California leading the way with over 700

David Ray Papke, professor, Law School, Marquette University. 
current death row prisoners (Lytle, 2008).

Selected Americans have opposed capital punishment throughout the history of its usage, but the opposition became more diverse, vocal, and passionate when the number of executions spiked in the mid-1990s. Amnesty International cast capital punishment as a violation of human rights, religious groups argued that capital punishment was sinful, and the Innocence Project began using DNA tests to show some people on death row and some who had already been executed were in fact innocent (Bakken, 2010).

How might the film industry have become part of the debate regarding capital punishment? Did Hollywood-feature films from the turn of the 21 st century take a detectable stance regarding capital punishment? The questions seem relevant since Hollywood has not avoided timely political issues in the cinema itself. "While Hollywood has traditionally defined its product as entertainment and has pooh-poohed 'message film-making' in practice, the industry has consistently relied on topicality as a crucial ingredient of box-office success" (Prince, 2000, p. 65). Then, Hollywood is frequently said to have a liberal bias, and this bias could conceivably manifest in films opposed to capital punishment, too. Indeed, individual Hollywood writers, actors, and directors of the periods expressed their personal opposition to capital punishment (Gaskins, 2010).

The first section of this article provides a brief history of the ways capital punishment has been used in the Hollywood cinema, emphasizing the effectiveness of capital punishment as a plot device in a surprisingly wide range of films. In the subsequent section, the article considers in depth five contemporary films that in admittedly dramatized and fictionalized ways seem to criticize capital punishment. The films make the case that individual characters do not deserve to die, but, in general, the films do not make the deeper, more profound argument that capital punishment is fundamentally immoral. The article then concludes by asking why contemporary films proffer such a "muted message" regarding the use of capital punishment.

\section{Capital Punishment as a Plot Device in Cinema History}

Although capital punishment surely does not dominate film history, capital punishment has played a role in the plots of more Hollywood films than one might think. In simplest terms, "plot" is the sequence of events and actions in a story. These events might be presented in the order in which they purportedly took place or in a wide range of other ways, but the pattern of the events engages viewers and provides artistic and emotional effects (Abrams, 1999). Sometimes, a writer or a filmmaker will use what is called as "plot device" to bring special energy to the plot, to promote characters' crucial decisions, or to create important ramifications. Capital punishment has served in surprisingly large number of films as an effective plot device of this sort.

This use of capital punishment dates back to the earliest days of the feature film, even to the days of silent black-and-white films. A good example is the appropriately named Capital Punishment (1925). The film seems terribly dated as it drips with the melodrama so common in early Hollywood productions. However, this kind of cinematic melodrama found a place for capital punishment or, at least, the possibility of capital punishment. In the film, Delia Tate, played by a young and winning Clara Bow, tries to rescue her boyfriend, who has ended 
up on death row when a prank went awry.

In the venerable western genre, capital punishment often looms as an undertaking of not just the state but also an outraged citizenry. In the critically praised Ox-Bow Incident (1943), vigilantes do the hanging. Searching for men they believe to be murderers and cattle rustlers, the vigilante mob finds three men sleeping in a canyon and lynches them. The mob then returns to town and learns that the supposed murder victim is alive and that the men who shot him have been arrested. Twenty-five years later in Hang 'Em High (1968), a mob tries to lynch cattleman Jed Cooper, played by a young Clint Eastwood, for murder. However, the mob rides off while Cooper is still dangling, and passers-by cut him down and clear his name. Cooper then becomes the marshal! In Good Day for Hanging (1959), the biases of the citizenry cut in just the opposite direction. They do not want to believe a charming young man was an accessory to murder and deserved to die, but the marshal, played by Fred MacMurray, is clear-headed enough to insist the sentence be carried out. In the modern western All the Pretty Horses (2000), the cinematic adaptation of Cormac McCarthy's superb novel, one of the three Texans who undertake a reckless journey to Mexico ends up being executed for horse stealing and other crimes. His two somewhat older colleagues barely escape a similar fate.

Film noir is another indigenous American film genre (Silver \& Ward, 1979), and it also has employed capital punishment as a plot device. As "the cinema of paranoia, of doubt and fear and uncertainty" (Dixon, 2009, p. 11), film noir could and did hold out capital punishment as sort of a final truth. Fritz Lang, one of the masters of the genre, cast Raymond Burr, who would later become indistinguishable from the righteous attorney Perry Mason, as a lusty playboy in The Blue Gardenia (1954). When he is found dead, Norah Larkin, played by Anne Baxter, encounters the wrath of the state and faces the death penalty. Later, in an odd twist in the genre, Lang cast Dana Andrews as the novelist Tom Garrett in Beyond a Reasonable Doubt (1956). Garrett allows his future father-in-law to frame him for a murder as part of a hair-brained scheme to expose and critique capital punishment. The viewer can predict almost from the start that things will backfire. Even The Man Who Wasn't There (2002), a Coen Brothers' spoof of the film noir genre, uses capital punishment as a potential and then actual punctuation point. Doris Crane, played by Frances McDormand, avoids the "death house" but only by committing suicide. Her husband Ed, played by Billy Bob Thornton, sells his story for five cents a word to a men's magazine and then goes to the chair without regrets.

Docudramas regarding actual cases in which convicted felons faced capital punishment have also been common in the history of the Hollywood cinema. In I Want to Live (1958), for example, actress Susan Hayward won an Oscar for her portrayal of the real-life Barbara Graham. The latter may in fact have participated in the murder of Mable Monahan by placing a plastic bag over her head. In the film, she is portrayed as a sacrificial lamb for two men who committed the crime but tell police she was the perpetrator. Her execution at the end of the film was modeled carefully on actual executions at San Quentin and included the painfully meticulous preparation of the gas chamber (Foster, 1997). In a later period, The Executioner's Song (1982) starred Tommy Lee Jones as the psychopathic murderer Gary Gilmore. In the film and in real-life, Gilmore insisted that he be put to death. The state of Utah accommodated his request with an old-fashioned firing squad. 
Beyond genre films that can use capital punishment as a central plot device, more individualized films have used capital punishment in a range of creative ways. Although different in thematic make-up, The Green Mile (1999) and Monster's Ball (2001) examine the impact of capital punishment on guards and prison executioners. And even a comedy such as My Cousin Vinny (1992). finds a place for at least the possibility of capital punishment. When attorney Vincent "Vinny" Gambino journeys from Brooklyn to Alabama to represent his nephew and a friend in a criminal proceeding, Vinny's bumbling is hilarious, except perhaps for the defendants who face execution if convicted.

The numerous ways in which capital punishment has been used in the plots of Hollywood films over the years illustrates the power of capital punishment as a plot device. The specter of the state executing somebody, even a truly guilty person, speaks loudly in a plot. The possibility of capital punishment is especially effective in creating suspense, that is, a situation in which viewers are uncertain about what will happen (Rabkin, 1974). In this way and others, capital punishment has been used throughout the history of the Hollywood film to capture and hold viewers' attention.

\section{Contemporary Films Regarding Capital Punishment}

All of the films mentioned in the previous section of this article use capital punishment or, at least, the looming possibility of capital punishment as grist in their plots. Sometimes, the grist is large and significant, while other times it is small and insignificant. More interesting for purposes at hand, meanwhile, are films that are in some sense "about" capital punishment, that is, films that explore state-authorized execution at length and, on some level, contemplate its practical viability and moral worth.

This section of the article will discuss five films of this sort. The films are fiction or fictionalized dramatizations of real cases, but none are documentaries. All were released since 1995, in the very period during which the debate in the United States over the future of capital punishment heated up. The films are surprisingly similar, but summaries of the individual films might be useful for readers who are unfamiliar with them.

Dead Man Walking (1995) is the most honored and accomplished one of the five films. It is derived from an exquisite memoir of the same name by Sister Helen Prejean (1993), in which the good Sister recalls her efforts to counsel two death-row inmates; she also recounts her meetings with relatives of both the inmates and the victims. Sister Prejean's opposition to capital punishment is absolutely clear. Before meeting with for the first time with Patrick Sonnier, one of the inmates, she says:

But even if he were unlikable and repulsive, even if he were Manson, I still maintain that the state should not kill him. For me, the unnegotiable moral bedrock on which a society must be built is that killing by anyone, under any conditions, cannot be tolerated. And that includes the government. (p. 31)

The film adaptation is faithful to the memoir in neither detail nor ultimate thrust. The film combines two of the men Sister Prejean counseled into one character named Matthew Poncelet, played by the actor Sean Penn. The actress Susan Sarandon took the part of Sister Prejean and won the Academy Award for Best Actress for her efforts. In the film, Poncelet is crude, racist, and sexist and at first claims his innocence. 
However, after many visits from Sister Prejean, Poncelet finally admits his guilt. When legal attempts to obtain a stay are unsuccessful, Poncelet apologizes to the parents of one of his victims and is then put to death. Shapiro (1996) has noted that while Sister's Prejean's memoir is unambiguous about the immorality of capital punishment, the film is more "evenhanded" in part because of the sympathetic portrayals of the victims' family members. The filmmaker Tim Robbins claimed he "was presenting both sides of the [capital punishment] issue" (p. 1157).

The year following the release and substantial commercial success of Dead Man Walking saw Hollywood release two more capital punishment films. Derived from a popular novel of the same name by John Grisham, The Chamber (1996) is the fictional story of a young attorney named Adam Hall, played by Chris O'Donnell, who tries to save the life of his grandfather Sam Cayhall, played by Gene Hackman. Cayhall is a Klansman in the Mississippi State Penitentiary and facing death for his killing of two Jewish children 30 years earlier. Hall's mission, it turns out, is as much about purging the ghosts of his family's ugly racist past as it is about saving Cayhall. The Governor denies Hall's request for clemency but promises to pursue others who seem likely to have been involved in the crime, and Cayhall meets his maker foaming from the mouth in an especially ugly death scene.

In Last Dance (1996), the person on death row is not a southern racist but a one-time crack addict. Cindy Liggett, played by Sharon Stone, killed two people in a drug-fueled rage during a break-in and was sentenced to death 12years earlier. With only 30 days left before her execution, Rick Hayes, played by Rob Morrow, attempts to convince the clemency board, the courts, and the Governor that Liggett is a changed and reformed person who deserves to live. Even though Hayes is an inexperienced lawyer, holding the "first real job" of his life, it seems that he will succeed. With Liggett already strapped to the table awaiting her lethal injection, the phone rings, the warden answers, and he orders everyone to stand down. But alas, newly discovered evidence and the argument that Liggett had ineffective representation by counsel are unconvincing. Liggett puts on the same dress, climbs back on the same table, and is put to death.

In True Crime (1999), Frank Beechum, played by Isaiah Washington, is on death row, having been convicted of killing a clerk in a convenience store. With the executions scheduled for the next day, the Oakland Tribune assigns senior reporter Steve Everett, played by Clint Eastwood, to cover the execution from a human interest perspective. Everett is a womanizer and a recovering alcoholic. In trouble with his editors and supervisors, he is sadly adrift in his personal and professional life. Nevertheless, Everett discovers a key witness to the murder has lied, and he hastily investigates and learns the identity of the true perpetrator. Everett races to the Governor's home and convinces him to stop Beechum's execution, and the Governor calls the prison just as Beechum is receiving the first of his fatal injections. If the reactions of Beechum's wife are any indication, the call is too late, but in an ambiguous postscript to the apparent execution, Beechum is seen alive.

The Life of David Gale (2003) shows a greater sense of irony than other capital punishment films, albeit only fleetingly. David Gale, a defrocked college English professor played by Kevin Spacey, is on death row, having been convicted of raping and killing Constance Harraway, played by Laura Linney. Gale and Linney are 
active campaigners against capital punishment, and, therefore, viewers see before their eyes a critic of capital punishment awaiting his own capital punishment! With only a few days left, Gale agrees to a financially lucrative deal to sell his story to journalist Bitsey Bloom, played by Kate Winslet. Bloom, in turn, discovers that Gale did not kill Harraway but was a party to her elaborately staged suicide. Bloom tries frantically to alert the authorities in order to stop the execution, but she arrives at the prison just as the warden is announcing Gale has been put to death.

As previously noted, the five films are remarkably similar. They manifest a pronounced sameness. This sameness includes both minor motifs and larger conventions as well as a consistent message about capital punishment. Overall, the films are not numerous enough to constitute a genre per se, that is, a variety of film which is so predictable as to sometimes attract-viewers as a type (Altman, 1999; Grant, 1977; Graves \& Engle, 1981; Schatz, 1972). Nevertheless, over roughly the last 15 years Hollywood has produced and distributed just one variety of capital punishment film with only one position on capital punishment.

The minor touches include familiar scenes, predictable secondary characters, and even clocks and phones on the walls of the execution venue. Among the scenes are such well tested favorites as the protests outside the prison walls, final visits from friends and visitors, the serving of the last meal, and the long walk to the execution venue, complete with brief but touching farewells from sympathetic guards as well as the other prisoners on death row. The latter are among the most important secondary characters, and the prisoners' bonding with the condemned speaks of comradeship and human solidarity. Less of a bond develops between the condemned and the earnest but ineffectual ministers and wardens, who invariably come calling. The execution itself, complete with the frightening strapping down of the condemned, acquires extra dramatic tension from the efforts outside the prison to save the condemned. Will the last-minute efforts succeed? Will the condemned be saved? Even in the age of cell phones and computers, a conventional phone hangs on the wall, and it may ring as the final minutes tick away. The condemned is usually courageous, more courageous in fact than members of the small audience assembled as witnesses. All eyes are focused on the round clock on the wall, and in the Hollywood cinema all executions take place at midnight.

In addition to these minor touches, two major features of the five films stand out. First, the person on death row is sympathetic and even appealing. The scholar David Dow (2000) argued that death penalty movies "cheat by featuring an innocent inmate" (p. 512), and this is literally true of Frank Beechum in True Crime and David Gale in The Life of David Gale. Beyond legal guilt or innocence, meanwhile, all the death row characters have traits and tendencies that make viewers like them. Cindy Ligett in Last Dance writes letters for her fellow inmates, loves to draw, and offers her brother heartfelt advice about how to right his ways. Despite his professed racism and anti-Semitism, Sam Cayhall in The Chamber shows remorse and regret for the murder of two Jewish children, seems to be protecting somebody else who actually planted the bomb, and says in the end, "Of all the things in the world I hated the one I hated most was me." And even in Dead Man Walking, after countless sessions with Sister Prejean, Matthew Poncelet finally takes responsibility for killing the male victim and raping the female victim. We, as viewers, approve when shortly before his execution, Poncelet asks the boy's parents for forgiveness and tells the girl's parents he hopes his death will 
bring them peace.

In addition to a sympathetic figure on death row, a second major character who observes and attempts to assist the character on death row appears in all of the films. In general, this second character is at least as important as the condemned. He or she may be a lawyer, as in The Chamber and Last Dance; a journalist, as in True Crime and The Life of David Gale; or even a nun as in Dead Man Walking. Whatever the case, the importance of the second character should not be underestimated. He or she grows as a person in the course of each film, developing not only a greater appreciation of the condemned but also finding his or her own way in life. As the secondary characters figuratively or often literally watch the minutes tick down toward execution, viewers watch as well, knowing the perceptions of the second characters can be trusted and even honored.

Added together, the motifs and conventions of the five films seem to admonish those who would use capital punishment, and a casual commentator might simply take the films to be critical of capital punishment (Harding, 2005). All of the featured characters on death row, after all, are innocent or, at least, appealing and/or redeemed. In bringing these characters to life, in filling them out as human beings, the films strengthen the sentiment that they should not be put to death. It is one thing to read the names of those who have been put to death or to review the statistics regarding the number of executions. It is quite another thing when one is forced to reflect on the full-blown humanity of a victim.

In addition, the films dramatize the actual executions in disturbing ways. The setting is invariably stark and chilling, and watching somebody be put to death or come close to being put to death is terrifying. The execution in The Chamber, with the drool and spittle glistening on the dead Sam Cayhall's face, is horrible. Viewers of the Last Dance, meanwhile, contemplate the execution of Cindy Liggett not once but rather two times. When the state executes somebody in real life, the frightening exercise of power is not in public. As the scholar Austin Sarat (1999) has observed, "Capital punishment becomes, at best, a hidden reality" (p. 156). The secrecy of the ceremony might instill fear in the public imagination, but still, only a handful of witnesses actually see it performed. When the contemporary capital punishment film takes us right into the execution venue and shows us how, albeit in a fictional way, the whole thing looks, we are forced to confront the horror and more likely to see it is problematic.

But despite all this, the five films do not leave us outraged by capital punishment per se. Instead, we are outraged by the execution of the particular character being featured. He or she does not deserve to die. We watch his or her execution or near-execution through the eyes of the lawyer, journalist, or nun who has grown and developed in the course of the film. This second character clearly appreciates that the condemned should not die, but the second character does not necessarily become a crusader against capital punishment in general. He or she just thinks that Matthew Poncelet, Sam Cayhall, Cindy Liggett, Frank Beechum, or David Gale should not die.

The message of the individual films and of the films as a group is thereby muted. While there is no endorsement of capital punishment, the films do not aggressively and persistently indict capital punishment. 


\section{Why Is the Message Muted?}

There is no conspiracy among Hollywood writers, actors, and directors. They have not schemed to offer only limited criticism of capital punishment. Indeed, as noted earlier, most writers, actors and directors take themselves to be opposed to capital punishment. But still, there are both financial reasons and cinematic reasons for the thrust of the five films on which this article focuses. The former reasons relate to profit, while the latter involve the standard ways the culture industry "circulates meanings and pleasures" (Fiske, 1989, p. 26).

With regard to the financial reasons, box-office considerations are preeminent. It is important to remember that the Hollywood film is a commodity produced for sale to mass audiences. Film production most certainly includes artistic work, much of it extraordinarily engaging, but there is a powerful financial logic operative in the film industry. Filmmakers want viewers to like their films and be willing to spend their money on them. Hence, filmmakers are loath to produce films that would alienate a significant percentage of the film-going population.

Public opinion regarding capital punishment during the years in which the five films were produced was equally divided, with a small majority favoring the continued use of capital punishment (Mallicoat, 2010). In addition, the polls for the period showed a widening divergence in the public opinion. Those who were neutral or had no opinion on the use of capital punishment were fewer and fewer in number. Positions grew more rigid, and a polarization was occurring (Karn, 2010). With good reason, Hollywood might have worried about the box-office potential of a film that in deep and unyielding ways condemned the institution of capital punishment and in the process alienated half the public.

Furthermore, norms in the Hollywood cinema itself limited what the five films could assert about capital punishment. To be more specific, in the years following the Great Depression and World War II, Hollywood fully "adopted the basic tactic and goal of the realist novel" (Ray, 1985, p. 34). This involved creating the illusion of reality and encouraging viewers to identify with a film's major character and to take pleasure in that character's accomplishments and personal growth. Once the cinematic norms were established, they took on momentum and became virtually imperative. It "risked not only commercial disaster but critical comprehension" to depart from the norms (Ray, p. 26).

When Hollywood turned to capital punishment in the 1990s, it did not break with the established paradigm, and, in fact, the five films considered in this article fit superbly well within the paradigm. All convey the illusion of reality, both within the prison walls and on the streets of town, where lawyers, journalists, and church women scurry to save the condemned. Furthermore, all the films feature appealing major characters. As previously noted, the condemned are innocent or, at least, redeemed and admirable. Even more importantly, their champions change and grow right before the viewers' eyes, and audience members identify more with these characters' heroism than with any cinematic campaign against capital punishment.

In the end, Hollywood's capital punishment cinema is a disappointment for the opponent of capital punishment. While it portrays interpersonally appealing men and women facing capital punishment in horrifying ways in terrible settings, contemporary films concerning capital punishment do not indict capital 
punishment in general. Since the message of the films is muted, contemporary Hollywood films have not become a major force in the contemporary campaign against capital punishment.

\section{References}

Abrams, M. H. (1999). A glossary of literary terms (7th ed.). New York: Harcourt Brace.

Altman, R. (1999). Film/Genre. London: British Film Institute.

Bakken, G. M. (2010). Introduction. In G. M. Bakken (Ed.), Invitation to an execution: $A$ history of the death penalty in the united states (pp. 1-14). Albuquerque, New Mexico: University of New Mexico Press.

Banner, S. (2002). The death penalty: An American history. Cambridge: Harvard University Press.

Burton, A. (2004). Pay no attention to the men behind the curtains: The Supreme Court, popular culture, and the counter majoritarian problem. UMKC Law Review, 73, 53-82.

Dixon, W. W. (2009). Film noir and the cinema of paranoia. New Brunswick, New Jersey: Rutgers University Press.

Dow, D. (2000). Fictional documentaries and truthful fictions: The death penalty in recent American film. Constitutional Commentary, 17, 511-513.

Fiske, J. (1989). Understanding popular culture. Boston: Uniwin Hyman.

Foster, T. (1997). I want to live! Federal values in death penalty cases: Preservation of rights or punctuality of execution? Oklahoma City University Law Review, 22, 63-87.

Gaskins, S. T. (2010). The celluloid execution: Hollywood films and capital punishment. In G. M. Bakken (Ed.), Invitation to an execution: $A$ history of the death penalty in the united states (pp. 137-190). Albuquerque, New Mexico: University of New Mexico Press.

Grant, B. (1977). Film genre: Theory and criticism. Metuchan, New Jersey: Scarecrow Press.

Graves, M., \& Engle, F. (1981). Blockbusters-A reference guide to film genres. Westport, Connecticut: Greenwood Press.

Harding, R. M. (2005). Reel violence: Popular culture and concerns about capital punishment in contemporary American society. In M. Freeman (Ed.), Law and popular culture (pp. 358-375). New York: Oxford University Press.

Karn, A. (2010). Amnesty international and the death penalty: Toward global abolition. In G. M. Bakken (Ed.), Invitation to an execution: $A$ history of the death penalty in the united states (pp. 115-135). Albuquerque, New Mexico: University of New Mexico Press.

Lytle, L. (2008). Execution's doorstep: True stories of the innocent and near damned. Boston: Northeastern University Press.

Mallicoat, S. C. (2010). Politics and capital punishment. In G. M. Bakken (Ed.), Invitation to an Execution: A history of the death penalty in the United States. Albuquerque, New Mexico: University of New Mexico Press.

Prejean, H. (1993). Dead man walking: An eyewitness account of the death penalty in the United States. New York: Random House.

Prince, S. (2000). Political films in the 1990s. In W. W. Dixon (Ed.), Film genre 2000: New critical essays (pp. 63-76). Albany: SUNY Press.

Rabkin, E. S. (1974). Narrative suspense. Ann Arbor, Michigan: University of Michigan Press.

Ray, R. (1985). A certain tendency of the Hollywood cinema: 1930-1980. Princeton: Princeton University Press.

Sarat, A. (1999). The cultural life of capital punishment: Responsibility and representation in dead man walking and last dance. Yale Journal of Law and the Humanities, 11, 153-190.

Schatz, T. (1972). Hollywood genres: Formulas, filmmaking, and the studio system. Philadelphia: Temple University Press.

Shapiro, C. (1996). Do or die: Does dead man walking run? University of San Francisco Law Review, 30, 1143-1166.

Silver, A., \& Ward, E. (1979). Film noir: An encyclopedic reference to the American style. Woodstock, New York: The Overlook Press. 